\title{
The effect of expertise on the quality of forest standards implementation: The case of FSC forest certification in Russia
}

\author{
Olga Maletz $^{\mathrm{a}, *}$, Maria Tysiachniouk ${ }^{\mathrm{b}, 1}$ \\ a Max Planck Institute for the Study of Societies, Paulstr. 3, 50676 Cologne, Germany \\ b Center for Independent Social Research, Ligovski pr. 87, Office 301, St. Petersburg 191040, Russia
}

\section{A R T I C L E I N F O}

Keywords:

Expertise

Experts

Forest certification

Forest management assessment

Environmental auditing

\begin{abstract}
A B S T R A C T
The central question of the paper is how differences in expertise affect the implementation of voluntary environmental standards in the forestry sector. Specifically we analyze the experience of two large forest companies in Russia that certified their forest management under the Forest Stewardship Council (FSC) forest certification program. Drawing on the literature on financial auditing we show that specific outcomes of forest management standards implementation are shaped by the differences in forest management auditors' knowledge, skills and attitudes.
\end{abstract}

(c) 2009 Elsevier B.V. All rights reserved.

\section{Introduction}

The goal of this paper is to examine the role of local experts in translating global forestry standards into practice. We define experts as actors claiming to have specialized knowledge and skills, which they derive from extensive training and practical experience, and recognized as experts by peers and external audiences (Krull and Anderson, 2001). We argue that experts play a crucial role in shaping the outcomes of the implementation of global environmental norms and standards in a specific local context. They interpret abstract global standards through the lens of their expertise and can influence how implementing actors apply standards. Experts can shape the actors' performance, especially when implementing actors are uncertain about how to achieve compliance with standards. The difference in experts' knowledge explains the variation in the implementation outcomes.

Specifically, we address the role that local experts play in translating global voluntary standards of forest management into specific practices in Russian forestry sector. We look at the Forest Stewardship Council (FSC) certification of forest management, the only forest certification program active in Russia, to examine how various groups of experts with specialized knowledge of forestry and forest certification shape the ways Russian forest companies change their practices to comply with FSC's global standards of good forest management. We show that differences in experts' knowledge and orientations are crucial for understanding differences in standard implementation at the level of a forest management unit. We draw our conclusions from two in-depth case-studies of certified forest

\footnotetext{
* Corresponding author. Tel.: +49 2212767 230; fax: +49 2212767555.

E-mail addresses: maletz@mpifg.de (O. Maletz), tysiachn@indepsocres.spb.ru (M. Tysiachniouk).

${ }^{1}$ Tel./fax: +7 8127183796 .
}

companies in the Republic of Karelia and Arkhangelskaya Oblast, two federal regions in northwest Russia ("Oblast" and "Republic" are administrative divisions of the Russian Federation). Working in similar conditions and having a similar organizational structure, they show striking differences in the implementation of forest certification environmental and social standards. We seek to highlight the role of experts in the process of certification and to understand their impact on organizational change.

We start with a brief description of forest certification as a global environmental governance project. We then describe the FSC certification procedure and identify key actors. After this we provide an analytical framework for understanding the role of expertise in translating standards into practices and review our methods and sources of data. In the next section we present the analysis of our cases. Drawing on the experience of Russian companies we then discuss the role of auditors in FSC standard implementation. In the concluding section we provide a summary of our contribution to the debate on the role of experts in forest governance.

\section{The FSC forest certification system: a case background}

Several environmental nongovernmental organizations (NGOs) and forest companies founded the Forest Stewardship Council (FSC) in 1993 to promote environmentally appropriate, socially beneficial and economically viable forest management in all regions of the world. The FSC developed ten principles and fifty-six criteria of good forest management and designed certification system based on the thirdparty assessment of forest operations' compliance with these principles and criteria. Forest operations that demonstrate compliance are granted a certificate that allows them to label their products with an FSC logo and market them as coming from appropriately managed 
forests. Forest certification helps buyers, retailers, and corporate and individual consumers recognize such products in the market. In turn, certified companies seek to benefit from increasing demand for certified products (Meidinger et al., 2003).

The FSC forest certification system has two main elements: standards of good forest management and third-party verification of compliance. Standards consist of principles, criteria and indicators. They refer to environmental, social and economic aspects of forest management. Principles and criteria are global. To be applicable in national or regional natural and social contexts, indicators reflecting national legislation, natural conditions, local culture and habitual forestry practices are specified.

The system of verification of compliance of forest management with the FSC standards is based on the annual assessments of forest operations' forest management conducted by professional certification bodies. Certification bodies are for-profit organizations formally independent from both the FSC as a standard-maker and forest companies as standard-implementers. They hire teams of experts in silviculture, forest biology, labor law and social issues. The experts are conventionally called auditors. These teams assess both operations' systems of forest planning and management and on-the-ground practices. Certification bodies grant FSC certificates if assessment teams verify company compliance with standards. If assessment teams detect non-compliance they issue corrective action requests (CARs) and require a company to correct non-compliance. CARs indicate which company practices need to be reformed.

In the FSC system of forest certification experts play the role of auditors who assess the compliance of forest operations with FSC forest management standards. On the one hand, they claim knowledge and skills of auditing forest management, including how to assess it and how to apply standards. On the other hand, they claim knowledge and skills of forestry and forestry-related issues in a specific domestic context. In the article we seek to explain the role that forest management auditors play in implementing the FSC global forest management standard.

Assessment procedures used in FSC forest certification system are inherently similar to financial auditing: "Independent auditing of companies' forest management practices, similar to the way accountants audit a company's financial transactions, is essential to make claims of sustainability credible" (Jenkins and Smith, 1999: 63). The goal of auditing-be it financial or environmental auditing-is to identify failures, gaps and non-compliance with existing norms and to suggest how audited organizations can improve their performance. In the next section, we review several insights from the literature on financial auditing that shed light on the role of auditors in forest certification.

\section{Analytical framework: lessons from financial auditing literature}

The question why some companies are more likely to seek forest certification than others is not new. Studies have shown that domestic and international pressure from activists, buyers, investors and consumers, the structure of domestic consumption and exports of timber, size of companies, associational structure of forestry sector, property regimes and government support shape the patterns of adoption of forest certification (Cashore et al., 2004, 2007; McNichol, 2006). These studies explain why some companies decide to certify their forests and reform their practices to comply with certification standards, but how exactly they do it remains an open question. It may be expected that companies that opted for certification reform their practices in a similar manner, since they follow a single standard. Yet, it is striking that companies in comparable circumstances follow very different paths of reforms.

Drawing on the literature on financial auditing (Power, 1996, 1997, 2003a,b; Strathern, 2000), we suggest that the key to this puzzle is in the inherent ambiguity of standards and certification procedures that requires implementing actors to interpret and negotiate their meanings in specific local circumstances. Standards are always formulated to be sufficiently general because they have to be applied to multiple typical situations, which are, however, never entirely identical to each other. In order to effectively apply standards local actors have to interpret both the standards themselves and the situations in which they act. In this way they can understand how they have to change their practices to make them fit the standard. What is the role of forest management auditors here? Similar to lawyers and judges that have specialized knowledge and skills to interpret laws and judge actions, auditors claim to have relevant knowledge and skills to interpret forest management standards, define what standards require and whether actual practices are in compliance with them.

In his work on financial auditing, Power shows that auditors are never completely independent, objective and neutral verifies of compliance. Rather, they act as "agents of change": their judgments shape trajectories of organizational transformation. Power (1997) demonstrates that no matter how precise the standards and rules are, auditors always retain certain discretion to interpret both rules and regulations because rules are never completely unambiguous. Moreover, no matter how well the rules guiding the behavior of auditors are specified, auditors never remain fully objective. Ultimately, it is impossible to entirely remove the subjectivity of auditors, and the probability that auditors will make a wrong judgment cannot be completely eliminated. It can only be reduced. Finally, Power (2003b) argues that auditors' knowledge and attitudes and the operational culture of the auditing bodies that they represent shape their judgments. Their judgments emerge not as an outcome of independent and objective assessment of documentation and practices but in the interaction between auditors and audited organizations. The relationship of interdependence develops between those who audit and those who are audited. This relationship shapes organizational change.

How do these ideas help us understand how auditing and auditors shape the trajectory of organizational change during certification? We hypothesize that auditors' judgments affect how audited companies change their practices to comply with FCS standards. Auditors' judgments in turn depend on their background and their theories about causal links between social and natural phenomena. Ultimately, the differences in auditors' background and beliefs determine the differences in companies' implementation of FSC standards.

The analysis we provide in the following sections should be treated as a starting point for more systematic qualitative and quantitative investigations of the impact of auditors and experts on the local implementation of forest management standards. Previous studies suggest that institutional design of forest certification initiatives and the structure of domestic policy networks shape the variability of the standard setting processes across forest certification initiatives, as well as differences across national or regional standards (Auld and Bull, 2003; Cashore and Lawson, 2003). The specific outcomes of standard application may be affected by the size of forest operations, local political context, the characteristics of social networks, the type of forest and other natural conditions or structural features of domestic forestry sector. These issues require more research; yet, they fall beyond the scope of this paper. We seek to examine in depth how the characteristics of auditors and experts involved in the certification of companies in similar structural conditions shapes forest management practices on the ground.

\section{Methods and data}

To provide evidence for our claims, we analyze the data we derive from two qualitative comparative case-studies of two large forest companies that operate in northwest Russia in similar natural and social conditions. To understand the dynamics of auditing during certification in these two companies, we interviewed auditors, 
company managers, workers, representatives of local communities and indigenous people and civil society organizations (related to both environmental and indigenous rights), which were involved in the certification. In total we conducted forty-two semi-structured interviews during a series of field studies in 2006-2007 in the forest settlements located near the forest areas managed by companies. From these data, we reconstruct the stories of two certifications and focus specifically on the role of auditors.

In addition, we used the interviews conducted by Maria Tysiachniouk earlier for other studies (Tysiachniouk and Meidinger, 2006; Tysiachniouk, 2006; Tysiachniouk et al., 2005; Tysiachniouk and Reisman, 2005). We also analyzed Tysiachniouk's field notes that she took during her observations at the FSC forest management audits at one of the two companies, annual meetings of certification bodies with the FSC officials, and meetings of FSC Russian national initiative in 2005-2007.

For our study, we selected two similar companies that operate in a comparable natural and social environment. One is Segezha Pulp and Paper Mill (PPM) located in the town of Segezha in the Republic of Karelia. The second is PLO Onegales, a group of logging operations, a chief supplier of raw materials to Onega Sawmill. Both PLO Onegales and Onega Sawmill are located in the town of Onega in Arkhangelskaya Oblast. Arkhangelskaya Oblast and the Republic of Karelia are two neighboring federal districts in the northwest Russia.

Segezha PPM and Onegales are both large companies managing significant forest areas. Segezha PPM was built in 1939, Onega Sawmills in 1928. When the companies were certified they did not have foreign owners. Both certified their forest management because they expected to benefit from higher prices for certified wood in European markets, to resolve conflicts with environmental NGOs, to avoid them in the future and to improve their international reputation. Both companies had to significantly improve their forest management systems and practices to become certified but demonstrated considerable differences in reforms, in particular in issues related to community relations and indigenous people rights. The companies are not direct competitors. Segezha PPM specializes mainly on the production of paper packaging materials for domestic and international markets. Onega Sawmills ships sawn wood to its established long-term partners in Germany and the Netherlands. In the following sections, we present our case-studies and then analyze them in the discussion session.

\section{Case-study one: certification of Segezha Pulp and Paper Mill}

Segezha Pulp and Paper Mill (PPM) is a large forest company operating in the Republic of Karelia. In 2007 due to a large investment and modernization program it acquired forest operations and production facilities in ten European countries and grew into a large international corporation-Investlesprom. Segezha PPM became one of the units of a new corporation. In 2005 Segezha PPM leased 1.8 million ha of forestland from the federal government to secure timber supply. Segezha PPM decided to certify its operations because in addition to the manufacturing of pulp and paper it ships round and sawn wood to Britain where many buyers prefer certified wood. Segezha's management also hoped to minimize its reputation risks and to reform the company's forest management. Segezha PPM received an FSC forest management certificate in 2007.

In its approach to certification Segezha PPM showed a genuine interest in improving its forest management and going beyond certification requirements. It developed truly inclusive and collaborative relationships with environmental NGOs, social activists and rural communities living near Segezha PPM's forests. However, it did not come naturally. As forest managers worked towards certification they recruited experts in environmental and social issues to help them fulfill certification criteria and worked closely with a certification body's assessment team.
When Segezha PPM decided to pursue certification they selected a certification body and arranged a pre-assessment of its forest management systems and practices. Several auditors attended and compiled a list of inconsistencies with the standard that could potentially become corrective action requests (CARs) at the main assessment audit. Segezha PPM did not hire consultants as many other companies do, hoping that their forest management was good enough to qualify for a certificate. However, managers lacked relevant knowledge necessary to define what exactly had to be done. They only contracted a local environmental NGO SPOK to identify endangered species and potential protected areas in Segezha's forests. Yet, by the time of the main assessment in July 2006 this work had not even been started. Managers had only a very vague idea of how to fulfill certification requirements.

It is therefore not surprising that at the main assessment auditors identified eight major CARs and twelve minor CARs and had to schedule another assessment before the certificate could be granted. Having experienced the difficulties of forest certification, Segezha PPM's managers developed closer relationships with an assessment team and experts from environmental and social NGOs who were able to help them translate abstract standards into specific practices.

After the main assessment auditors encouraged Segezha PPM to cooperate with local environmental nongovernmental organizations. Segezha PPM followed auditors' recommendations and supported the work of SPOK, a local environmental NGO, with which they already cooperated before the main assessment. SPOK identified endangered species and high conservation value forests at Segezha PPM's forestland. In 2006-2007, Segezha PPM funded SPOK's project to develop a methodology for identifying key biotopes in the region. Thanks to Segezha's support, the manual was published in 2007. Other companies operating in Karelia could also use it to improve their forest management. Although certified companies are obligated to develop and implement systems of forest protection, such a cooperation goes beyond what auditors in other certification bodies required from their clients. Moreover, in 2007 Segezha PPM continued their cooperation with local civil society organizations and sponsored several environmental projects initiated by local communities, including the development of an environmental trail for a local high school.

Additionally, it recruited a team of sociologists specializing on local community participation in natural resource management to help improve the company's relationships with local forest communities. Sociologists were closely involved in the certification assessment and identified the core problems of Segezha PPM in community relationships. They contributed to raising the awareness of local citizens about certification and the additional responsibility that FSC certification requires from forest operations. They explained to local citizens and forest workers how FSC functions and how citizens could use certification to defend their interests. Sociologists also arranged individual consultations with local community leaders to map forests that communities wanted to protect from logging for their traditional forest use.

Sociologists also encouraged the company to contribute to preserving cultural heritage of the Karels, the indigenous population of Karelia. Although the majority of the Karels assimilated, many families, schools and civil society organizations are engaged in preserving elements of traditional life, including music and applied arts. Following their recommendations, Segezha PPM supported a series of cultural projects of local civil organizations.

Invited experts were aware that they were working towards making Segezha PPM certifiable, i.e. they were aware that whatever they did had to be documented and reported in terms of FSC forest certification indicators. To do so they interpreted and reinterpreted certification requirements, as well as adjusted their own actions to criteria and indicators. Yet, they were also deliberately pushing the company to go beyond compliance with certification requirements. 
They convinced the company to organize a model forest on a part of its leased forests. The model forest is a stakeholder-based project funded mainly (but not solely) by Segezha PPM to test economic, social and environmental innovations in forestry and forest community development. This goes beyond certification standards and was only possible because of certification and individual experts involved.

After the re-assessment in February 2007 the certification body granted Segezha PPM an FSC certificate. In July 2007 Segezha PPM successfully passed the first annual inspection audit.

The success of Segezha PPM can be explained by the open and positive attitude of its managers but it alone cannot be held responsible for Segezha PPM's good performance. The experts that Segezha PPM invited to help them achieve compliance with social and environmental principles and criteria of forest certification considerably contributed to shaping the improvements in company's community relations and forest management. The experts had extensive experience with forest management and forest certification that they acquired both in Russia and internationally. SPOK successfully worked with international environmental organizations, including Greenpeace, on various projects in northwest Russia. They criticized the local government and forest service for weak enforcement of forestry rules and outright violations of forest legislation. At the same time, they developed manuals and techniques for identifying rare species and key biotopes specifically in Karelia, thus accumulating the knowledge of local environmental and social conditions.

Sociologists that Segezha invited as consultants on community relations also had extensive experience in forest certification and community relations that they also acquired both in Russia and through the participation in international projects in Russia and abroad. They studied community participation in the model forests that Russian and international environmental NGOs, including World Wide Fund for Nature (WWF), created to develop "best practices" in forest management for Russia. They also studied the experience of the first certified companies and engaged in forest certification processes as stakeholders. They also took an active part in developing the FSC national standard for Russia.

Using their knowledge that company managers did not have, both environmental and community participation experts shaped the specific practices in biodiversity protection and community involvement. The positive attitude of company managers undoubtedly facilitated the improvement of practices, but without expert knowledge and pressure for change the trajectory of change could have been different. In the process of certification, both experts and auditors directed the company towards higher compliance standards. Experts tried to develop creative and effective ways towards compliance and even pushed Segezha PPM for over-compliance. However, there are still many practices in place that experts consider below the desired level of compliance.

\section{Case-study two: the certification of PLO Onegales}

PLO Onegales is a major raw materials supplier of Onega Sawmill, large wood processing company in the town of Onega in Arkhangelskaya Oblast. It sources timber from six smaller forest operations. These operations are formally separate legal entities that delegated their management to Onegales. Although each operation leases forestland individually from the federal government, in practice Onegales manages these forests, as well the operations themselves. In turn, they are obligated to sell all its wood to Onegales, which supplies it to the sawmill or sells it to other customers. One of the operations holds a separate FSC certificate and was certified first in 2003; the remaining five operations hold a FSC group certificate issued in 2005. The total certified area equals approximately 1,460,000 ha.

Onega Sawmill and Onegales decided to certify their sources of timber as well-managed after their major buyers in Germany and the Netherlands declared that they would only purchase certified timber from their suppliers in Russia. In addition, environmental campaigns organized by Greenpeace and other international organizations in the end of the 1990s to protect old-growth forests forced Onegales to stop logging in areas identified by campaigners as old-growth. Under the pressure of Greenpeace and other radical environmental organizations Onegales signed a five-year moratorium on logging old-growth forests. These campaigns also encouraged Onegales to certify its forest management to avoid further confrontation with environmentalists that could damage their reputation and undermine their sales.

Yet, the relationship between NGOs' activists and Onegales did not develop into genuine cooperation and remained implicitly confrontational. Although Onegales had to give up logging forests that environmentalists defined as old-growth, the managers never agreed that these territories should be protected from logging. They insisted that the state forest service and environmental agencies were responsible for identifying protected areas and it was not in the jurisdiction of NGOs supported by international sponsors to impose restrictions on logging in these forests. The managers were unwilling to accept NGOs as legitimate actors. Onegales was prepared to go back to logging forests recognized by NGOs as old-growth as soon as they had a chance to do it. It insisted that old-growth forests did not have any particular environmental value and have to be logged like other commercial forests.

A certification body that Onegales contracted to assess its forest management relied mainly on consultants and auditors that it recruited from a local forest research institution. The assessment team included also international auditors. They relied extensively on the expertise of local auditors. Onegales also hired consultants from the same local forest research institution. Consultants and auditors interpreted certification standards, on the one hand, to make them applicable to specific conditions of Onegales' forest management and, on the other hand, help the company re-structure its documentation and practices to make them fit certification criteria and indicators. Consultants following auditors' recommendations developed measures to protect biodiversity and improve worker safety. This enabled Onega Sawmill and Onegales to achieve high ranking in the environmental rating system designed by rating agency Expert RA together with WWF (WWF Russia, 2006).

However, as far as the issues of community relations and indigenous peoples' rights were concerned, Onegales adopted a minimalistic formalistic approach that activists for indigenous people rights later strongly criticized. Auditors and experts put emphasis on environmental issues, but they lacked relevant knowledge and experience to develop appropriate measures to ensure equal participation of local communities in forest management and were unable to identify and address potential conflicts with indigenous communities.

The group certification of forest operations managed by Onegales took a long time: The certification of the whole group of operations followed the first certification only after 2 years. The pre-assessment of forest management and main assessment in both cases found a significant number of inconsistencies with FSC standards (when the group of five operations was certified twenty-three CARs were issued) that Onegales had to resolve within a period between 2 weeks and 5 years. The company had to present evidence that they took action to ensure compliance, but this evidence was not documented for the public by the auditors. In both cases the certificates were granted. Annual inspections apparently proved that Onegales did not violate certification standards specified by the certification body and auditors, since their certificates were not withdrawn. However, we were unable to find public summaries of annual inspection reports on the certifier's web site.

In 2006, shortly after certification local NGOs raised concern about the lack of consultations with local organizations representing local indigenous people, the Pomors. The status of the Pomors as an indigenous people is not officially recognized, and they are not included in the official register of indigenous groups living in Russia. 
Onegales ignored communities struggling for recognition. Although evidence existed that the logging of one the Onegales's certified operations damaged forests where a Pomor community traditionally hunted, auditors did not consult with the NGOs and ethnologists that tried to attract company's attention to this problem. The NGOs sent grievances to certification bodies, auditors and Onegales' management but received no immediate reply. Management's position was that the Pomors should not be recognized as an indigenous people and that the company does not harm their traditional forest use. Only after the FSC's national office for Russia intervened and encouraged Onegales to respond to the NGOs' grievances did Onegales and the auditors organize a series of meetings with the NGOs and local community representatives to discuss problems and solutions.

Moreover, the relationship with local communities affected by Onegales' activities (both logging and other measures like log transportation) was also very confrontational. Communities were not properly informed about forest certification; community consultations were only occasional and formalistic. There was also no working grievance resolution procedure. Communities were unaware of their right to complain, according to FSC standards. It has to be noted that when the first forest operation of Onegales Malashuykales applied for certification, its managers together with the experts they hired developed a plan of community development for the settlement of Malashuyka, where Malashuykales was based, and developed a grievance procedure. However, Malashuykales' managers did not make enough effort to encourage local population to make use of this procedure and actively participate in the decision-making concerning the use of forest resources. Moreover, this experience was not appropriately replicated in the remaining five operations that were certified as a group in 2005.

In case of Onegales certification, experts did not push the company towards higher standards. They interpreted standards in the most company-friendly way and rather reduced FSC standards and the company's level of attainment in forest management to the lowest common denominator. They viewed NGOs' suggestions on how to improve their forest management and community relationships as illegitimate and were unwilling to cooperate. They also did not recognize local communities and indigenous people because experts' and the company's definition of indigenous groups differed from the definition advocated by indigenous community rights activists. The case of Onegales shows that the lack of experts specializing in community relations and indigenous people in an auditing team leads to a rash dismissal of these issues as irrelevant. They are, however, crucial for communities that depend on the forest resources jointly used by companies and local population. Empowering local people and securing long-term social benefits is one of the three central pillars of the FSC's forest certification and requires equal attention of auditors and certification bodies.

\section{Discussion}

The results of two qualitative case-studies presented in the previous sections suggest that auditors and other actors who claim expertise in certain issues related to forest management, e.g. community relationships or indigenous people rights, shape the implementation of private standards in forest management. Although the task of auditors is to assess company compliance with FSC standards of good forest management, what they define as noncompliance guides company reforms of their forest management.

FSC forest management standards and auditing procedures are the basic rules that structure the activity of actors at the local level. They prescribe roles and behavioral models for each actor and shape mutual expectations. Nevertheless, when standards and procedures are applied in specific circumstances, they require additional interpretation. FSC generic standards provide actors with a general idea of what is expected of them, but when actors respond to these guidelines in real-life situations they interpret the standards based on their knowledge, experience and personal dispositions.

For example, when companies are required to inform their workers and local populations about forest certification, their stakeholder status and grievance procedures, managers may choose to publish this information in a local newspaper that only a few read or organize public presentations and discussions and personally invite local people to attend. When companies are required to coordinate their activity with communities of indigenous people, they may stick to the federal registers of indigenous peoples or actively seek cooperation with local communities even if they are not officially recognized but identify themselves as indigenous or practicing traditional forest use. The standard does not necessarily specify how exactly this has to be done. Auditors, nonetheless, have to know what to check, while managers have to meet their expectations. What auditors require may thus lead company managers in very different directions.

Forest companies are certainly not passive in the implementation of standards but they often lack knowledge, skills and time to deal with problems themselves. Moreover, they are often unaware of certifiers' expectations. They hire consultants familiar with certification procedures to help them meet certification requirements. The contribution of auditors and consultants is crucial. They bring in knowledge that managers of forest companies responsible for logging and silviculture lack. They are the key figures in certification who actually know how producers should implement standards to obtain a certificate.

Two case-studies demonstrate that auditors' background, knowledge and attitudes are important factors shaping the path of organizational change for certified companies. In the case of Segezha PPM, NGOaffiliated auditors and consultants with international experience saw their mission in convincing business to change their harmful practices and worked to set up higher standards that might even exceed FSC standards. They put more pressure on the company and tried to convince it that sustainable forest management and not the certificate per se should be a genuine goal of certification. Nonetheless, they were also well aware of what a company could actually do under local constraints and were able to compromise their higher standards to keep a company motivated for further improvements.

In the case of Onegales, the team consisted of international and Russian auditors. International auditors did not have enough local knowledge to properly assess some aspects of Onegales' activity, in particular their conflicts with local communities. Russian auditors did not have enough international experience and were not familiar with the local and international NGOs that monitored Onegales activity and were therefore unable to address their concerns. Auditors supported producers and interpreted standards in a less strict, more formalistic manner. They dismissed the FSC's principle three (recognition and respect of indigenous peoples' rights) as not applicable. They adopted a pragmatic formalistic approach to certification and helped companies pursue certification while keeping the costs minimal. Even after NGOs and the representatives of indigenous communities urged Onegales to address indigenous rights issues, the company initially resisted to do it but was ultimately convinced to discuss the problems of indigenous communities.

In sum, according to their personal predispositions and knowledge, auditors and experts interpret standards differently and translate them into practices that may be quite different from those of their peers. The actual certification outcomes may be quite different depending auditors' and experts' qualifications and knowledge. The issues that experts interpret differently include high conservation value forests and in general what kind of forests (and how much) a company should preserve; old growth forests; logging techniques and rules; indigenous people; and relationships with local communities.

Several factors can be invoked to explain how auditors influenced the different paths of change two companies followed towards 
certification. One such factor is the timing. Onegales started the certification process 4 years earlier than Segezha PPM. By the time Segezha PPM certified its forest management, the development of forest certification was more advanced than at the time when Onegales started certification. Forest certification was no longer an unfamiliar practice. Certification bodies and consultants accumulated sufficient experience in certification. The single national standard for Russia (in contrast to standards of individual certification bodies) was being developed, although it was still far from completion. It may be therefore argued that because of this the certification of Segezha PPM took less time than the certification of Onegales and Segezha was less resistant to experts' demands.

This observation reinforces our argument suggesting that the experience and knowledge of auditors and consultants shapes the transformation of corporate practices. Learning and accumulation of experience are key processes that influence organizational change over time. Our argument is not that auditors certifying Onegales deliberately excluded indigenous people from the management of forest resources which were vital to their well-being. Rather we suggest that these practices were not initially a part of their repertoire and that it took time for indigenous communities and NGOs representing their interests to overcome Onegales' resistance and convince Onegales and the auditors to start a dialogue with indigenous communities.

It can be also argued that it is rather the interests of auditors and certification bodies, rather than their expertise, that dictate how they assess the compliance of companies with FSC standards and what corrections they require from those companies. Moreover, it can be hypothesized that companies and certifiers may form interest coalitions to achieve certain outcomes.

Our data suggest, however, that this is an unlikely explanation. Certification bodies are interested in maintaining a good reputation because companies certify their forest management to resolve or avoid conflicts with NGOs and buyers and problems with certification can undermine their efforts. Through annual accreditation assessments, spontaneous audits and stakeholder grievances the FSC is able to monitor and control certifiers' performance. Neither companies nor certifiers are therefore likely to deliberately deceive the FSC and its stakeholders. Rather, auditors and certification bodies may diverge in their assessments because of differences in their background, knowledge and attitudes. This is confirmed by the fact that Onegales and the auditors, who initially resisted acknowledging the Pomor communities as indigenous, agreed to meet with the NGOs representing these communities and discuss the impact that its activity might have on community well-being.

\section{Conclusion}

Our study demonstrates that expertise and experts are not neutral. These differences in the perceptions of the world coupled with different backgrounds and personal dispositions of actors shape the ways experts use their knowledge to shape standard implementation during certification of forest management. The standards may therefore be differently adjusted to the similar local contexts by different certification bodies and auditors. The result is that at the stage of implementation similar companies in a similar environment follow a different path towards compliance with standards.

Although both companies opted for forest certification for pragmatic reasons and operated in a similar natural and social environment, they displayed qualitative differences in how they pursued certification. In certain ways Segezha PPM went slightly beyond certification requirements in improving its forest management and consciously tried to avoid formalistic approach to forest certification. It has developed genuinely inclusive relationships with local population, scientific community and environmental activists with an explicit goal of facilitating social change at the local level.
Onegales, on the contrary, adopted a formalistic style in certification and was reluctant to developing any dialogue with indigenous rights activists. These different styles have been shaped and backed up by certification bodies, auditors and consultants involved in the certification of these companies.

As actors interact they struggle about the correct ways of interpreting the world around them and in particular the new responsibility towards forest-dependent communities and indigenous people that certification brings. The experts in Segezha PPM case recognized the importance of local citizen expertise, while experts of Onegales resisted it. We show in our study that expertise is a key element in this process. It shapes the specific ways the social and environmental change is brought about at the local level.

Our study shows that auditors can interpret criteria and indicators in the way they believe to be most favorable for them, certified companies and society at large, and that these understandings differ. Formally, as long as companies are not required by certification bodies and their auditors to thoroughly consult with communities and respect indigenous rights, they feel no obligation to do so. There is no doubt that certification bodies cannot demand that companies immediately implement significant changes in their forest management systems. Yet their decisions about what to require from companies often depends on their vision of the world and their knowledge, which may be restrictive as in the case of Onegales or enabling as in the case of Segezha PPM.

\section{Acknowledgments}

The work of Maria Tysiachniouk was supported by the Finnish Academy of Sciences (Grant 121428). We are grateful to two anonymous reviewers and guest editors of the Forest Policy and Economics for their helpful comments. We thank Brian Milakovski for language editing.

\section{References}

Auld, G., Bull, G.Q., 2003. The institutional design of forest certification standards initiatives and its influence on the role of science: the case of forest genetic resources. Journal of Environmental Management 69, 47-62.

Cashore, B., Lawson, J., 2003. Comparing Forest Certification in the U.S. Northeast and the Canadian Maritimes. Canadian-American Public Policy, Occasional Paper 53. Canadian-American Center, Toronto.

Cashore, B., Auld, G., Newsom, D., 2004. Governing Through Markets: Forest Certification and the Emergence of Non-State Authority. Yale University Press, New Haven.

Cashore, B., Egan, E., Auld, G., Newsom, D., 2007. Revising theories of nonstate marketdriven (NSMD) governance: lessons from the Finnish forest certification experience. Global Environmental Politics 7, 1-44.

Jenkins, M.B., Smith, E.T., 1999. The Business of Sustainable Forestry: Strategies for an Industry in Transition. Island Press, Washington, D.C.

Krull, D.S., Anderson, C.S., 2001. Acquisition of expertise. In: Smelser, N.J., Baltes, P.B. (Eds.), International Encyclopedia of the Social and Behavioral Sciences. Elsevier, Amsterdam.

McNichol, J., 2006. Transnational NGO certification program as new regulatory forms: lessons from forestry sector. In: Djelic, M.-L., Sahlin-Andersson, K. (Eds.), Transnational Governance: Institutional Dynamics of Regulation. Cambridge University Press, Cambridge, pp. 349-374.

Meidinger, E., Elliott, C., Oesten, G., 2003. The fundamentals of forest certification. In: Meidinger, E., Elliott, C., Oesten, G. (Eds.), Social and Political Dimensions of Forest Certification. Remagen-Oberwinter, Forstbuch, pp. 3-25.

Power, M., 1996. Making things auditable. Accounting, Organizations and Society 21, 289-315.

Power, M., 1997. The Audit Society: Rituals of Verification. Oxford University Press, Oxford.

Power, M., 2003a. Auditing and the production of legitimacy. Accounting, Organizations and Society 28, 379-394.

Power, M., 2003b. Evaluating the audit explosion. Law \& Policy 25, 185-202.

Strathern, M. (Ed.), 2000. Auditing Cultures: Anthropological Studies in Audit, Ethics and Academia. Routledge, London.

Tysiachniouk, M., 2006. NGO mezhdu Globalizatsiey i Lokalizatsiey: Rol Globalnykh Protsessov v Mobilizatsii Obschestvennogo Uchastiya v Lesnykh Poselkakh. In: Tysiachniouk, M. (Ed.), Negosudarstvennye Mekhanismy Upravleniya v Globalnom Obschestve. Intersotsis, St. Petersburg, pp. 113-158 (in Russian).

Tysiachniouk, M., Reisman, J., 2005. Market of values across the border: forest practices on certified territories in Northwestern Russia. In: Rosenholm, A., Autio-Sarasmo, S. 
(Eds.), Understanding Russian Nature: Representations, Values and Concepts, Alexanteri Paper No. 4. Alexanteri Institute, Helsinki, pp. 147-176.

Tysiachniouk, M., Meidinger, E., 2006. using forest certification to strengthen rural communities: cases from Northwest Russia. Buffalo Legal Studies Research Paper No. 2006-011. Baldy Center for Law and Social Policy. State University of New York, Buffalo.
Tysiachniouk, M., Kuliasova, A., Pchelkina, S., 2005. Vliyanie Lesnoi Sertifikatsii na Sotsialnye Protsessy v Mestnykh Soobschestvakh Severo-Zapada Rossii. Jurnal Issledovaniy Sotsialnoy Politiki 3, 305-325 (in Russian).

WWF Russia, 2006. Ekologicheskaya Otvetstvennost v Lesnom Bisnese. Kto est Kto? Ustoichivoe Lesopolzovanie 11, 43-44 (in Russian). 